\title{
The species of Eucera Scopoli, subgenus Tetralonia Spinola from Sardinia (Italy) with new records and E. gennargentui sp. nov. (Hymenoptera, Apidae)
}

\author{
Roberto Catania', Vittorio Nobile², Salvatore Bella' \\ I (CREA) Consiglio per la ricerca in agricoltura e l'analisi dell'economia agraria, Centro di Ricerca olivi- \\ coltura, frutticoltura e agrumicoltura, Corso Savoia 190, I-95024 Acireale (CT), Italy 2 Via Psaumida 17, \\ lotto 25, I-97100 Ragusa, Italy
}

Corresponding author: Salvatore Bella (salvatore.bella@crea.gov.it)

Academic editor: Michael Ohl | Received 29 June 2021 | Accepted 25 November 2021 | Published 30 December 2021

http://zoobank.org/510FBE37-39CF-4332-B105-59DF9EC9F65D

Citation: Catania R, Nobile V, Bella S (2021) The species of Eucera Scopoli, subgenus Tetralonia Spinola from Sardinia (Italy) with new records and E. gennargentui sp. nov. (Hymenoptera, Apidae). Journal of Hymenoptera Research 88: 1-16. https://doi.org/10.3897/jhr.88.70819

\begin{abstract}
In this paper, an update of the species of the genus Eucera Scopoli, 1770, subgenus Tetralonia Spinola, 1838 from Sardinia is reported, based on data collection as well as on recent survey carried out at Gennargentu Massif. Seven species are recorded, four of which are newly added: Eucera fulvescens (Giraud, 1863), E. gennargentui sp. nov. Nobile, Catania \& Bella, E. julliani (Pérez, 1879), and E. nana (Morawitz, 1873). The new species, Eucera (Tetralonia) gennargentui Nobile, Catania \& Bella is described from the high altitude of Gennargentu Massif. Details on distributions, host plants, and other biological aspects are given for each species treated. The taxonomic comparison of the taxa belonging to the subgenus Tetralonia from Sardinia, including E. gennargentui sp. nov., are discussed taking into account both morphological and COI barcode sequences. An identification key to Eucera (Tetralonia) species from Sardinia is also provided.
\end{abstract}

\section{Keywords}

Apidae, Eucera (Tetralonia), new taxon, Mediterranean bees, Sardinia

Copyright Roberto Catania et al. This is an open access article distributed under the terms of the Creative Commons Attribution License (CC BY 4.0), which permits unrestricted use, distribution, and reproduction in any medium, provided the original author and source are credited. 


\section{Introduction}

Belonging to the Eucerini tribe, Eucera Scopoli, 1770 is a genus of bees widespread in the world (Michener 2007), with a relevant number of species in the Palaearctic region and especially in the Mediterranean Basin (Tkalcu 1979, 1984; Risch 1997, 1999, 2001, 2003; Michener 2007; Dorchin et al. 2018). In their recent taxonomic studies Dorchin et al. (2018) treated the genus Tetraloniella Ashmead, 1899 within Tetralonia Spinola, 1838, and this last as a subgenus of Eucera.

The subgenus Tetralonia includes different oligolectic species, some of them closely associated and specialised with plants of the Asteraceae family (Müller 2008). The species of this subgenus have been revised for the Afrotropical region by Eardley (1989), for the New World by LaBerge (2001), and by Tkalcu $(1979,1984)$ for the Palaearctic region.

Eucera (Tetralonia) includes eleven species in Italy and some endemic subspecies of the main Italian islands, such as E. dentata amseli (Alfken, 1938) described from Sardinia and E. alticincta bindai (Nobile, 1993) described from Sicily (Alfken 1938; Nobile 1993).

To date, the knowledge on Sardinian bees is still limited, and only three species of Eucera (Tetralonia) are known: E. dentata amseli, E. graja (Eversmann, 1852) and E. malvae (Rossi, 1790) (Comba 2019; Nobile et al. 2021). This last species was recently found 78 years after its last report (Nobile et al. 2021).

In this paper, we add a further four species of Eucera (Tetralonia) as new for Sardinia and describe a new endemic species E. gennargentui sp. nov. Nobile, Catania \& Bella from Gennargentu Massif, based on both morphological and molecular data.

\section{Materials and methods}

The material examined belongs partly to the collection of Vittorio Nobile and partly comes from field collecting efforts carried out by the two other authors in Sardinia during the year 2020 .

Species identification was based on the works of Tkalcu $(1979,1984)$ and Scheuchl (2000). Morphological terminology and taxonomic classification follow Michener (2007) and Dorchin et al. (2018). Reference was made to the online 'Check-list of Western Palaearctic Bees' by Kuhlmann et al. (2018) and of 'Hymenoptera: Apoidea: Anthophila of Italy' by Comba (2019).

Observations in the field on Eucera gennargentui sp. nov. were made in the first week of August 2020 in the locality of Bruncu Spina, near the town of Fonni $\left(40^{\circ} 01^{\prime} 48.0^{\prime \prime} \mathrm{N}\right.$, $\left.9^{\circ} 17^{\prime} 56.6 \mathrm{E} \mathrm{E}\right)$, in the central area of Gennargentu Massif, at $1540 \mathrm{~m}$ a.s.l., characterized by several endemic high mountain species plants (Bacchetta et al. 2013) (Fig. 1); observations were carried out from 09:30 to 16:30, on the flowers of the Asteraceae family.

Gennargentu Massif is located near the centre of the island, almost directly at $40^{\circ}$ N. Bruncu Spina, at 1829 m a.s.l., is the second highest mountain in Sardinia, 

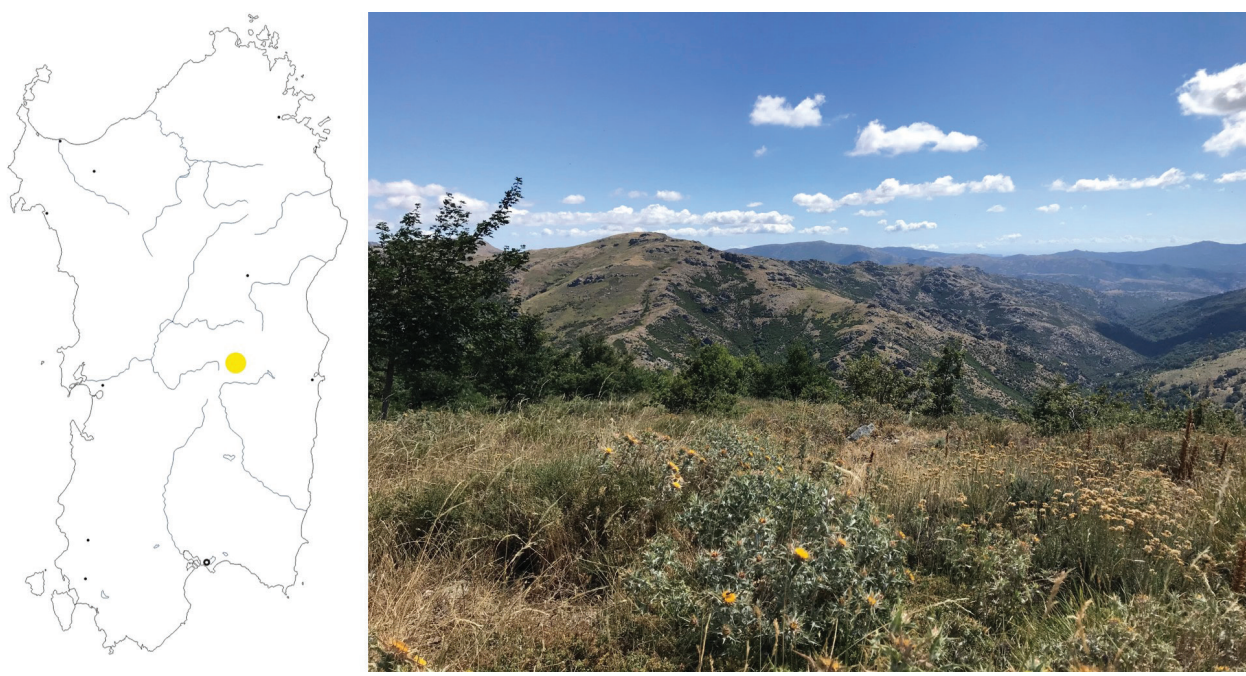

Figure I. Sardinia and Gennargentu Massif, locality of Bruncu Spina, $1540 \mathrm{~m}$ a.s.l., the site of the samplings of Eucera gennargentui sp. nov.

after Punta La Marmora (1834 $\mathrm{m}$ a.s.l.), and is the northernmost summit of the main Gennargentu ridge.

In order to collect biological data on the new taxon, some specimens were marked using a dye specific to bees. The date of capture, general and Italian distribution, number of specimens observed, and the plants visited are reported for all species.

Each specimen was killed by freezing at $-20^{\circ} \mathrm{C}$ for use in DNA analysis and was dried and identified to species level after the observation of genital structures. The specimens were preserved in the collection of the authors, and in the collection of the Department of Agriculture, Food and Environment, sect. Applied Entomology, University of Catania (Di3A).

The specimens were studied with a stereomicroscope Leica EZ4HD, the photos taken with a Leica Application Suite vs. 4.13.

Total DNA was extracted from one posterior leg using the NucleoSpin Tissue Kit (Macherey-Nagel, Germany) following the manufacturer's instructions. Subsequently, the enzymatic amplification took place using primers LCO1490F and HC02198R (Folmer et al. 1994). PCR products were purified using ExoSAP-IT (ThermoFisher Scientific) and were sequenced at BMR genomics (Padua, Italy), and the sequences obtained were analysed using MEGA X 10.2.4 (Kumar et al. 2018).

The sequences were aligned with seven COI sequences of Eucera (Tetralonia) available in GenBank, and we also included two sequences of Habropoda tarsata (Spinola, 1838) (accession numbers MN919536, MN919537) as an outgroup (Table 1). Sequence divergences were calculated using the $p$-distance model (Srivathsan and Meier 2012), and a neighbour-joining (NJ) tree (Saitou and Nei 1987), as implemented in MEGA X, was used to visualize the distance matrix among taxa. 
Table I. Analyzed sequences with accession number and origin countries.

\begin{tabular}{lcc}
\hline \multicolumn{1}{c}{ Species } & Accession number & Country \\
\hline Eucera alticincta alticincta & MNHNL005-20 & Luxembourg \\
Eucera alticincta bindai & MZ437367 & Italy, Sicily \\
Eucera dentata & FBAPD711-11 & Germany \\
Eucera fulvescens & ABEE208-17 & Austria \\
Eucera gennargentui sp. nov. & MZ437082 & Italy, Sardinia \\
Eucera graja & MG251108 & - \\
Eucera malvae & FBAPC604-11 & Germany \\
Eucera nana & ABEE206-17 & Austria \\
Eucera salicariae & FBAPC749-11 & Croatia \\
Habropoda tarsata & MN919536 & Italy, Sicily \\
Habropoda tarsata & MN919537 & Italy, Sicily \\
\hline
\end{tabular}

\section{Acronyms}

Di3A Department of Agriculture, Food and Environment, Catania, Italy;

RC Roberto Catania, Catania, Italy;

SB Salvatore Bella, Catania, Italy;

VN Vittorio Nobile, Ragusa, Italy.

\section{Results}

Detected species

Genus Eucera Scopoli, 1770

Subgenus Tetralonia Spinola, 1838

Eucera dentata amseli (Alfken, 1938)

Fig. 2

Tetraloniella dentata amseli Alfken, 1938, Mem. Soc. Entomol. It., 16: 97-114.

Data from literature. Alfken 1938.

Material examined. 1 o ; ITALY Sardinia, Iglesias, San Pietro (Cagliari province); 12.VII.1976.

Distribution. Sardinia and Corsica.

Range in Italy. Sardinia.

\section{Eucera fulvescens (Giraud, 1863)}

Tetralonia fulvescens Giraud, 1863, Verh. zool.-bot. Ges. Wien, 13: 42-43.

Material examined. 1 q; ITALY Sardinia, Busachi (Oristano province); 10.VI.1975; coll. C. Meloni - D. Sechi. 


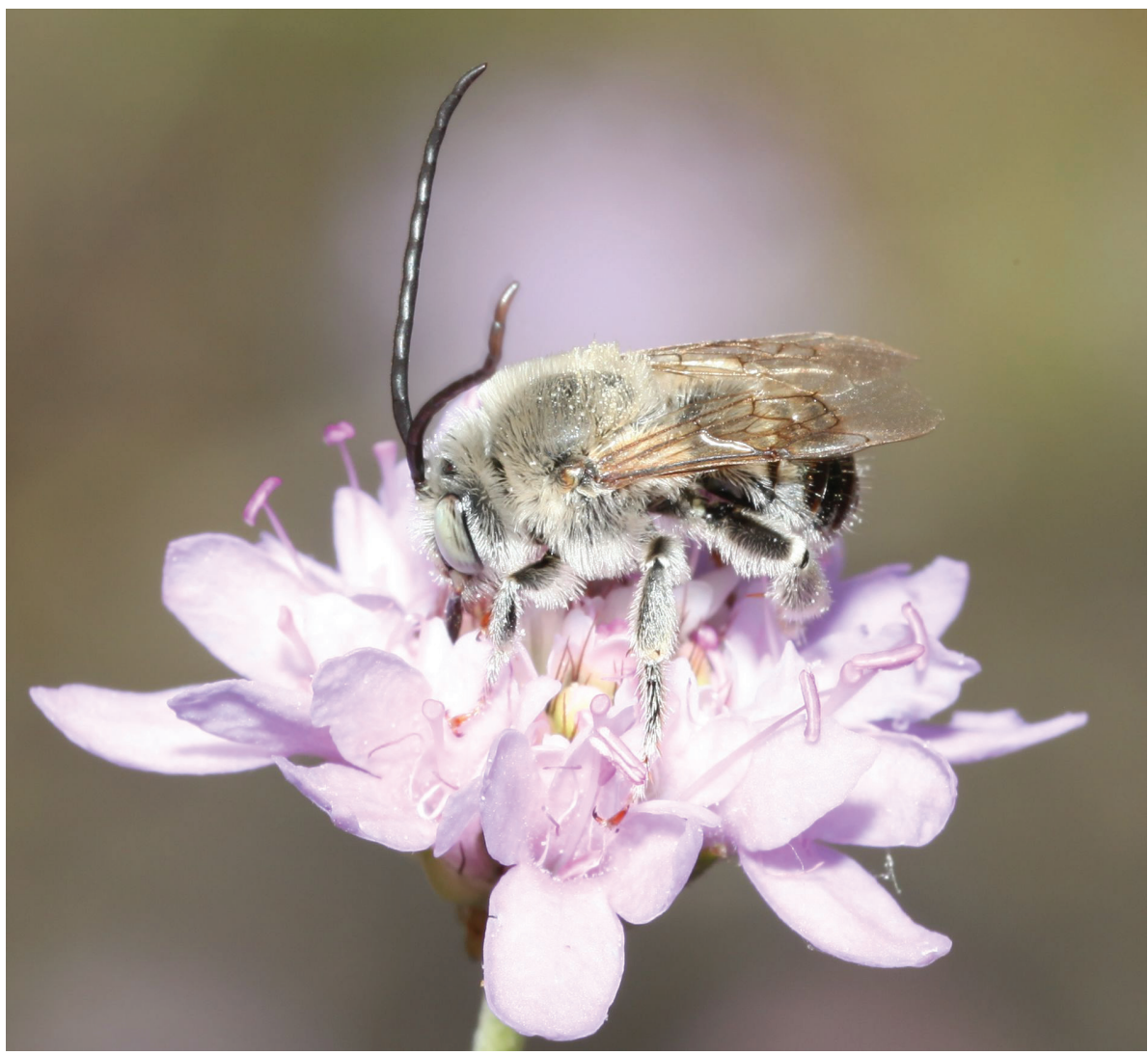

Figure 2. Male of E. dentata amseli Alfken. Sardinia, Ittiri (Photo by P. Niolu).

Distribution. South Europe, North Africa, West and Central Asia (Tkalcu 1979). Range in Italy. This species is discontinuously present in the Italian peninsula and Sicily.

New record for Sardinia

\section{Eucera gennargentui Nobile, Catania \& Bella sp. nov.}

http://zoobank.org/B12C779B-9542-4C49-ADE2-3E1F07D99A43

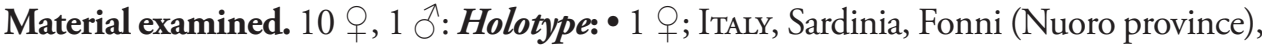
Gennargentu Massif, Bruncu Spina, 1540 m a.s.l.; 6-8.VIII.2020; S. Bella and R. Catania leg.; Di3A. Paratypes: • 9 q, 1 ô; paratypes identical data to previous; Di3A, RC, VN, SB.

Description. Female (Fig. 3). Body length: $10 \mathrm{~mm}$. Body with black integument with fine and evident punctation, grey setae. Head. Head with wrinkled punctation, finer at the edges and with white setae; clypeus black, with the lower half light yellow; this spot, extending upwards, and in the middle part, ends with a triangulated tip; labrum and mandibles black, antennae dorsally black, ventrally orange, with scape and 

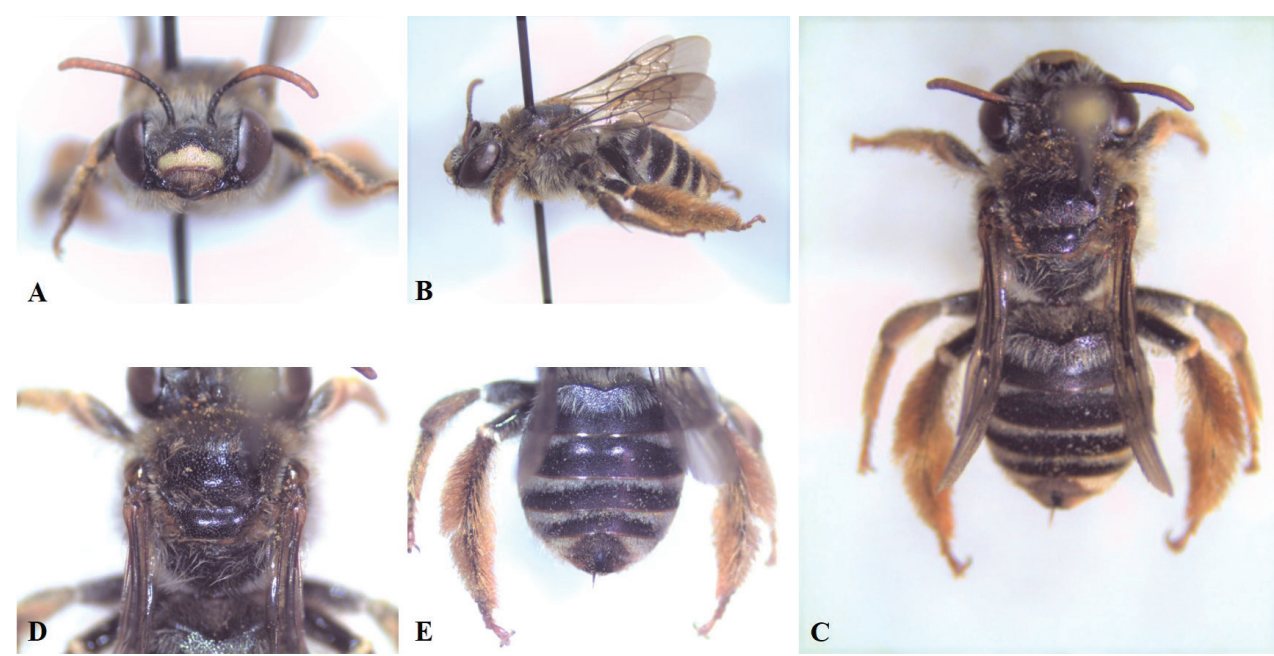

Figure 3. Eucera gennargentui sp. nov., female (A-E) A head, anterior view $\mathbf{B}$ habitus, lateral view $\mathbf{C}$ dorsal view $\mathbf{D}$ mesosoma, dorsal view E metasoma, dorsal view. (Photos by R. Catania).
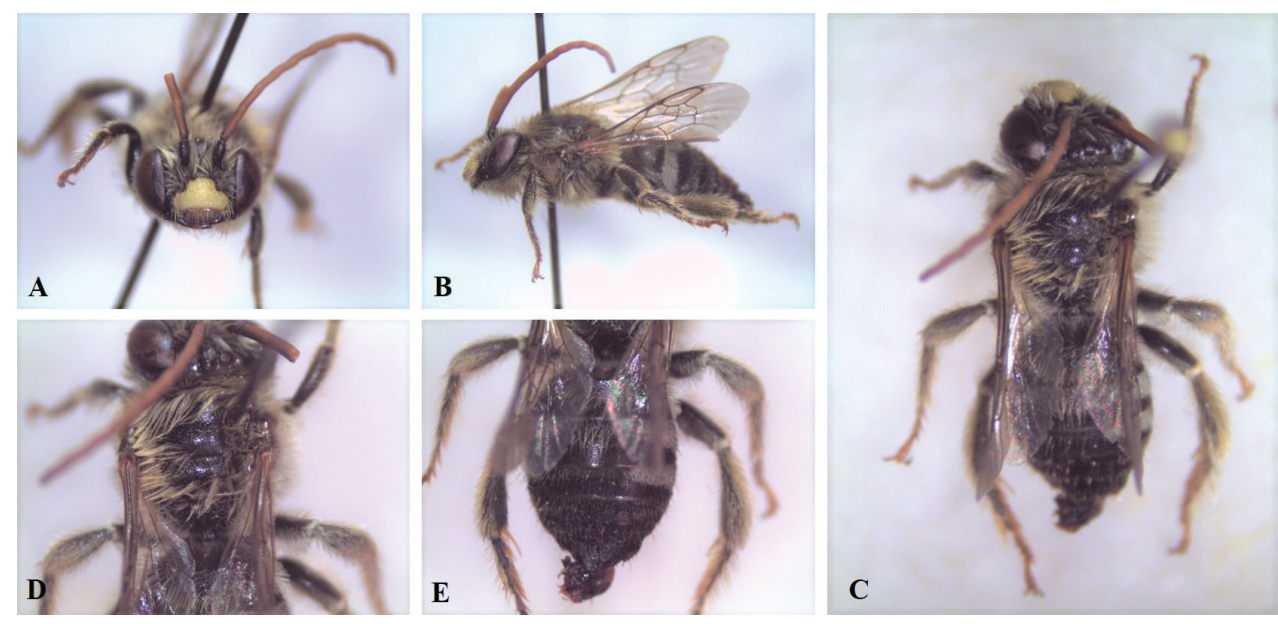

Figure 4. Eucera gennargentui sp. nov., male (A-E) A head, anterior view $\mathbf{B}$ habitus, lateral view $\mathbf{C}$ dorsal view $\mathbf{D}$ mesosoma, dorsal view $\mathbf{E}$ metasoma, dorsal view. (Photos by R. Catania).

first two flagellar articles black. Mesosoma. Mesothorax with greyish setae, median part of the metathorax with dense and large punctation. Black legs with greyish setae and the last four tarsi brown; the hind legs are equipped with a uniformly yellow-rust-coloured pollen-collection system. Slightly darkened wings, with black veins and dark brown tegulae. Metasoma. Dark brown, almost black, with dense and fine punctation. T1 with long and sparse white setae, T2-4 with basal bands of white felt, T5 with white felt on the sides and dark brown in the middle, and T6 almost completely covered with darkbrown felt. Dark-brown sternites with thick punctation and long golden-yellow fringes. 

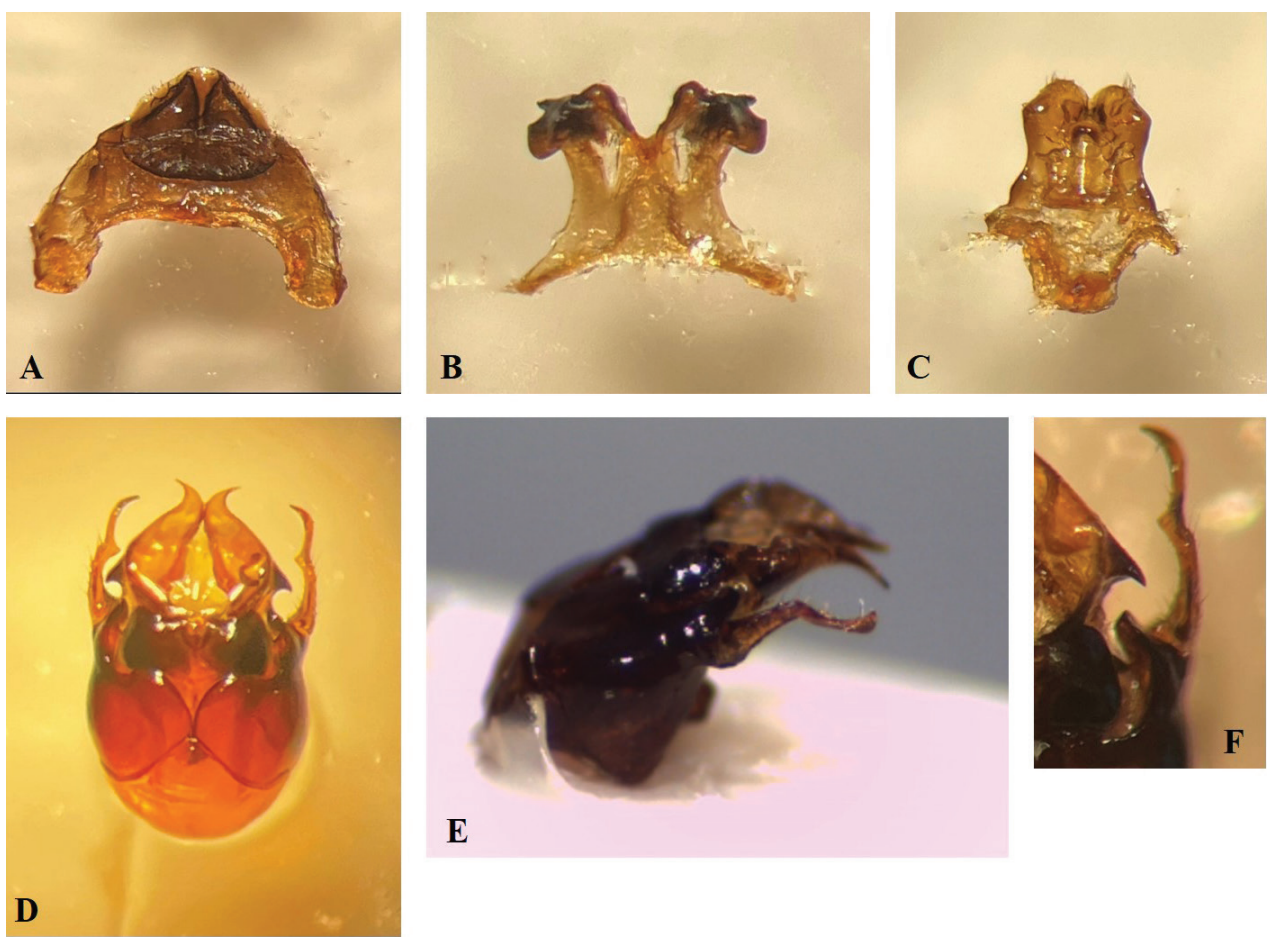

Figure 5. Eucera gennargentui sp. nov., genitalia and hidden sterna (A-F) A S6 ventral view B S7 ventral view $\mathbf{C}$ S8 ventral view $\mathbf{D}$ genitalia, dorsal view $\mathbf{E}$ genitalia, lateral view $\mathbf{F}$ vision of gonostylus and posterodorsal projection of gonocoxa (Photos by R. Catania).

Male (Figs 4-5). Body length: $9 \mathrm{~mm}$. General appearance similar to the female, with yellow clypeus and labrum, antennae are more than half of the body length long and reddish, except for a black streak on the whole dorsal part; black scape; mandibles are black, but reddish in the distal half. Mesosoma. With long silky whitish setae. Black legs with whitish setae. The hind femur, in the lower median part, has a small pointed tubercle equipped with a tuft of brownish bristles. Metasoma. As in the female, is dark brown, but all segments are covered with white felt, and T6 on the sides has 2 prominent teeth, one on each side. The last sternites are provided with a long and deep longitudinal median sulcus. Genitalia and hidden sterna. S6 without anterolateral marginal projections; posterolateral carina curved laterally at each side. $S 7$ with medial process rounded and attached at the posterior lobes of lateral processes; the posterior lobes of lateral processes are relatively short with straight superior margins; anterior lobes of lateral processes wide with straight superior margins and rounded lateral-inferior margins. S8 with a wide concavity between rounded apical lobes; apicomedian ventral process well defined and saddle shape, with a large depressed area at the base. Genital capsule with the apex of the gonostylus remarkably arched, and inward-facing triangular protuberance placed slightly over the central part of the gonostylus. 
Table 2. Morphological comparison between Eucera gennargentui sp. nov. and the closest related taxa.

\begin{tabular}{|c|c|c|}
\hline E. alticincta alticincta & E. alticincta bindai & E. gennargentui sp. nov. \\
\hline \multicolumn{3}{|c|}{ Female } \\
\hline 1) slim overall appearance & $\begin{array}{l}\text { 1) compact and robust overall ap- } \\
\text { pearance }\end{array}$ & 1) slim overall appearance \\
\hline 2) mesosoma with sparse punctation & 2) mesosoma with dense punctation & 2) mesosoma with denser punctation \\
\hline 3) metasoma ovoidal & 3) metasoma subspherical & 3) metasoma ovoidal \\
\hline $\begin{array}{l}\text { 4) } 3^{\circ} \text { and } 4^{\circ} \text { metasomal tergites with white, broad, } \\
\text { median tomentose band, slightly narrowing in the } \\
\text { middle }\end{array}$ & $\begin{array}{l}\text { 4) } 3^{\circ} \text { and } 4^{\circ} \text { metasomal tergites with } \\
\text { white, broad, median tomentose } \\
\text { band, deeply narrowing in the middle }\end{array}$ & $\begin{array}{l}\text { 4) } 3^{\circ} \text { and } 4^{\circ} \text { metasomal tergites with } \\
\text { white, broad, median tomentose } \\
\text { band, deeply narrowing in the middle }\end{array}$ \\
\hline 5) white long fringes on the metasomal sternites & $\begin{array}{l}\text { 5) white long fringes on the meta- } \\
\text { somal sternites }\end{array}$ & $\begin{array}{l}\text { 5) yellow-gold long fringes on the } \\
\text { metasomal sternites }\end{array}$ \\
\hline 6) scopa whitish externally and brownish internally & $\begin{array}{l}\text { 6) scopa whitish externally and yel- } \\
\text { lowish internally }\end{array}$ & 6) yellow-rust scopa \\
\hline 7) pigidial plate normally thinned & 7) less thinned pigidial plate & 7) pigidial plate normally thinned \\
\hline 8) body length $=7 \mathrm{~mm}$ & 8) body length $=8 \mathrm{~mm}$ & 8) body length $=9-10 \mathrm{~mm}$ \\
\hline \multicolumn{3}{|c|}{ Male } \\
\hline 1) compact overall appearance & 1) less compact overall appearance & 1) less compact overall appearance \\
\hline 2) brownish-yellow long silky mesosomal setae & $\begin{array}{l}\text { 2) brownish-yellow long silky meso- } \\
\text { somal setae }\end{array}$ & 2) whitish long silky mesosomal setae \\
\hline 3) metasomal ovoidal (longer than wide) & $\begin{array}{l}\text { 3) metasomal subspherical (as long } \\
\text { as wide) }\end{array}$ & $\begin{array}{l}\text { 3) metasomal ovoidal (longer than } \\
\text { wide) }\end{array}$ \\
\hline $\begin{array}{l}\text { 4) } 3^{\circ} \text { and } 4^{\circ} \text { metasomal tergites with white, broad, } \\
\text { median tomentose band, slightly narrowing in the } \\
\text { middle }\end{array}$ & $\begin{array}{l}\text { 4) } 3^{\circ} \text { and } 4^{\circ} \text { metasomal tergites with } \\
\text { white, broad, median tomentose } \\
\text { band, deeply narrowing in the middle }\end{array}$ & $\begin{array}{l}\text { 4) } 3^{\circ} \text { and } 4^{\circ} \text { metasomal tergites with } \\
\text { white, broad, median tomentose } \\
\text { band, deeply narrowing in the middle }\end{array}$ \\
\hline $\begin{array}{l}\text { 5) } 1^{\circ}-4^{\circ} \text { metasomal sternites distally with fringe of } \\
\text { dense, bristly, short and protruding light ivory setae } \\
\text { (more developed those on the } 2^{\circ} \text { and } 3^{\circ} \text { ) }\end{array}$ & $\begin{array}{l}\text { 5) } 1^{\circ}-4^{\circ} \text { metasomal sternites without } \\
\text { fringe }\end{array}$ & $\begin{array}{l}\text { 5) } 3^{\circ}-5^{\circ} \text { metasomal sternites distally } \\
\text { with fringe of short and protruding } \\
\text { yellow setae }\end{array}$ \\
\hline 6) normal pigidial plate & 6) less wide pigidial plate & 6) normal pigidial plate \\
\hline 7) body length $=8 \mathrm{~mm}$ & 7) body length $=7 \mathrm{~mm}$ & 7) body length $=9 \mathrm{~mm}$ \\
\hline
\end{tabular}

Difference with the closest related taxa. The new species Eucera gennargentui, is similar to $E$. alticincta (Lepeletier, 1841), including the nominate subspecies and E. alticincta bindai.

In the female of E. gennargentui, the long fringes of the sternites are yellow-gold, whereas in the closest related species $E$. alticincta alticincta, they are white; the scopa is yellow-rust in the new species, whitish externally and brown internally in E. alticincta alticincta.

In the male of the new species, the long silky hairs of the mesosoma are whitish, while they are brownish-yellow in E. alticincta alticincta. Genitalia of E. gennargentui is very similar to that of $E$. alticincta alticincta, however, in the gonostylus the inward-facing triangular protuberance, that in E. alticincta is located in the middle part, in the new species is placed slightly over half of the gonostylus, slightly closer to the apex. Further differences can be noted in the morphology of the hidden sterna, especially for the medial and lateral processes in S7, and for apical lobes and apicomedian ventral process in S8.

In both sexes of the new species, the integument and wings are considerably darker than E. alticincta alticincta, and the body length of both sexes of E. gennargentui is greater than that of the related species.

Further morphological and bio-ecological comparisons between E. alticincta alticincta, E. alticincta bindai, and E. gennargentui are reported in Tables 2 and 3.

Derivatio nominis. We named the new species after Gennargentu Massif, where the specimens were found. 
Table 3. Geographic and bio-ecological comparison between Eucera gennargentui sp. nov. and the closest related taxa.

\begin{tabular}{l|c|c}
\hline \multicolumn{1}{c|}{ E. alticincta alticincta } & E. alticincta bindai & E. gennargentui sp. nov. \\
\hline $\begin{array}{l}\text { Widespread in Europe, North Africa, } \\
\text { and western Asia (Varnava et al. 2020) }\end{array}$ & $\begin{array}{c}\text { Sicily (Nobile, 1987; 1993), Nebrodi Mts (Messina province), } \\
\text { northern slope of Mt Etna (RC, pers. observ.), and Syracuse } \\
\text { province }\end{array}$ & $\begin{array}{c}\text { Central Sardinia, Gennar- } \\
\text { gentu Massif }\end{array}$ \\
\hline \multicolumn{3}{c}{ Host plants } \\
\hline $\begin{array}{l}\text { oligolectic on Inula and Pulicaria } \\
\text { (Tkalcu, 1979; Müller, 2008) }\end{array}$ & observed on Pulicaria (RC, pers. observ.) & $\begin{array}{c}\text { oligolectic on Carlina, He- } \\
\text { lichrysum, and Tanacetum }\end{array}$ \\
\hline \multicolumn{2}{c}{ Environments } \\
\hline Temperate and Mediterranean & Mediterranean and Mediterranean mountains (100 - 1350 m \\
a.s.l.) & $\begin{array}{c}\text { Mediterranean high } \\
\text { mountains (1540 m a.s.l.) }\end{array}$ \\
\hline \multicolumn{2}{c}{ Phenology (generation and months) } \\
\hline probably univoltine; VII-VIII & probably univoltine; VIII-IX & probably univoltine; VIII \\
\hline
\end{tabular}

Distribution. Sardinia (Italy).

Flower choices. Specimens of the new taxon were observed on Carlina macrocephala Moris subsp. macrocephala, Tanacetum audibertii (Req.) DC. (Sardo-Corsican endemisms), and Helichrysum saxatile Moris subsp. saxatile (Sardinian endemism) (Asteraceae) (Fig. 6).

Bio-ecological aspects. A total of 22 specimens (half captured and half marked) were observed in the sampling site: 20 females and 2 males. Specimens of E. gennargentui were observed in activity in a restricted area of about $300 \mathrm{~m}^{2}$, from 10:30 to 15:00; in particular, the females visited the flowers from 10:30 to 14:30, and the two males were observed from 13:30 to 15:00 on Carlina macrocephala subsp. macrocephala. The female specimens visited the same flowers at intervals of about ten minutes, with a preference for the flowers of Carlina macrocephala subsp. macrocephala.

To know better the flights period of E. gennargentui, further surveys in the same site were conducted during mid-July 2021, however no specimens were found. This confirms the relationship between the new species and its main host plant, in fact Carlina macrocephala subsp. macrocephala was at the beginning of its flowering.
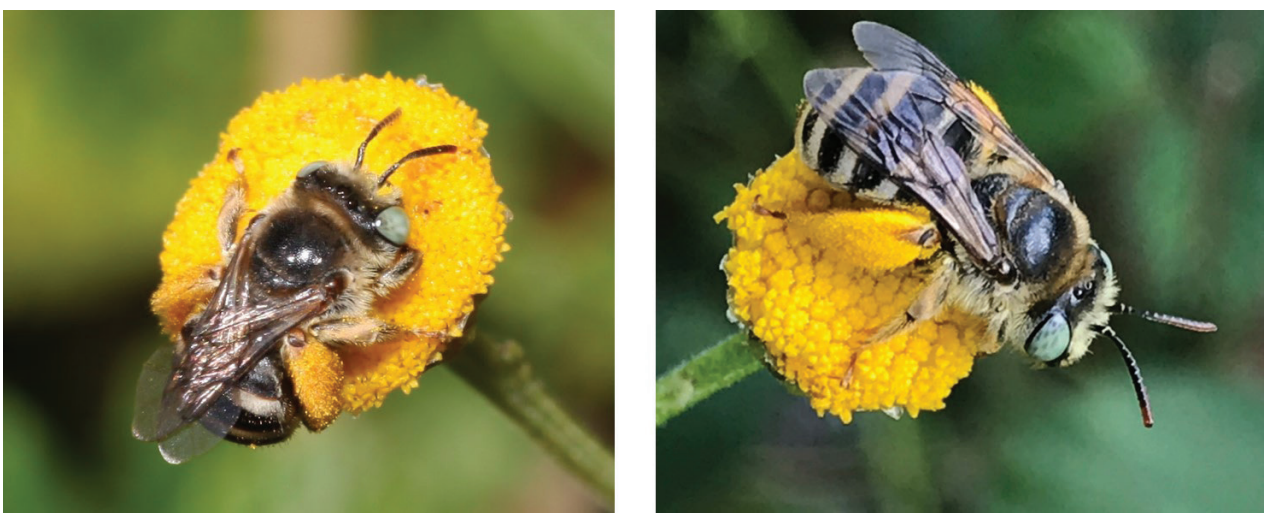

Figure 6. Female of Eucera gennargentui sp. nov. Sardinia, Gennargentu Massif, locality of Bruncu Spina (Photos by P. Niolu - R. Catania). 


\section{Eucera graja (Eversmann, 1852)}

Macrocera graja Eversmann, 1852, Bull. soc. natural. Moscou. 25: 124.

Data from literature. Grandi 1962 (Ozieri, Sassari province); Comba 2019.

Distribution. South and Central Europe, and West Asia (Banaszak \& OrtizSànchez 1993).

Range in Italy. This species is discontinuously present in the Italian peninsula, Sardinia and Sicily.

\section{Eucera julliani (Pérez, 1879)}

Macrocera julliani Pérez, 1879, Act. Soc. Linn., 33: 150.

Material examined. • 1 क; ITALY Sardinia, Assemini (Cagliari province); 3.IX.1990; L. Fancello leg. 1 ơ; Sardinia, Rio Flumini Mannu (Cagliari province), 2.VII.1992; C. Meloni leg.; on Ammi visnaga (L.) Lam. (Apiaceae).

Distribution. Turanic-South-European (Nobile 1987).

Range in Italy. This species is discontinuously present in the Italian peninsula, and Sicily.

New record for Sardinia

Eucera malvae (Rossi, 1790)

Apis malvae Rossi 1790, Fauna Etrusca II, p. 107.

Data from literature. Nobile et al. (2021).

Material examined. 1 O , 1 Oे; ItALy Sardinia, Capoterra, Rio S. Lucia (Cagliari province); 4.VI.1985; C. Meloni leg.

Distribution. Widespread in Europe, Eastern Mediterranean (Cyprus) and Western Asia (Turkey).

Range in Italy. This species is discontinuously present in the Italian peninsula, and Sicily.

\section{Eucera nana (Morawitz, 1873)}

Tetralonia nana Morawitz, 1873, Horae soc. entom. Ross. X, p. 144.

Material examined. 1 1 ; ITALY Sardinia, Teulada, Tuerru (South Sardinia province);

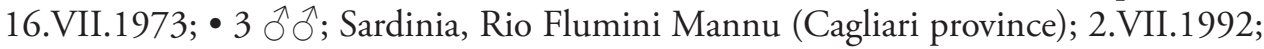
C. Meloni leg.; on Ammi visnaga (L.) Lam. (Apiaceae). 
Distribution. Widespread in Europe, and Western Asia (Turkey).

Range in Italy. This species is known in the regions of $<\mathrm{br} />$

.New record for Sardinia.

\section{Identification key to Eucera (Tetralonia) from Sardinia}

\section{Female:}

Clypeus more or less yellow ………….................................................. 2 Antennae ventrally light red, except for the scape and 1-2 flagellar articles that are black 3 Scopa dark brown externally and even darker internally. 12-14 mm.

Male:

Antennae ventrally more or less dark brown...........................................

Antennae ventrally light red except for the scape black................................5

Labrum and the lower part of the clypeus yellow. 11-13 mm .......E. malvae T6 laterally with short and stocky teeth, one on each side, facing backwards. $8 \mathrm{~mm}$ E. nana

More tergites with teeth, larger body size

In addition to clypeus and labrum, the base of the mandibles is yellow, T 5-6 with short and stocky teeth. $10 \mathrm{~mm}$ E. dentata amseli Mandibles black, T5-7 with slightly longer and sharper teeth. 11-12 mm ...

E. fulvescens

5 Clypeus, labrum, supraclypeal space and mandible yellow. 11-13 mm

E. graja

Mandibles and supraclypeal space black

.6

In the genital capsule the apex of the gonostylus facing inwards are almost straight. 9-10 $\mathrm{mm}$

E. julliani

- In the genital capsule the apex of the gonostylus are remarkably arched. $9 \mathrm{~mm}$ 
Table 4. $p$-distance and nucleotide divergences (expressed as percentages) of Eucera gennargentui sp. nov., E. alticincta bindai, and Eucera (Tetralonia) species with Habropoda tarsata used as the outgroup. Average distance: 12.25 .

\begin{tabular}{llccccccccc}
\hline $\mathbf{1}$ & Eucera gennargentui sp. nov. & & & & & & & & & \\
$\mathbf{2}$ & Eucera alticincta bindai & 2.21 & & & & & & & & \\
$\mathbf{3}$ & Eucera alticincta alticincta & 2.08 & 1.21 & & & & & & & \\
$\mathbf{4}$ & Eucera fulvescens & 4.09 & 3.55 & 3.41 & & & & & & \\
$\mathbf{5}$ & Eucera graja & 7.65 & 7.31 & 7.47 & 7.47 & & & & & \\
$\mathbf{6}$ & Eucera dentata & 8.34 & 8.0 & 8.05 & 8.68 & 8.34 & & & & \\
$\mathbf{7}$ & Eucera salicariae & 7.30 & 6.95 & 6.68 & 6.82 & 7.65 & 8.20 & & & \\
$\mathbf{8}$ & Eucera nana & 7.69 & 8.84 & 8.07 & 8.84 & 9.61 & 8.84 & 6.92 & & \\
$\mathbf{9}$ & Eucera malvae & 7.82 & 8.0 & 8.51 & 7.44 & 6.43 & 8.81 & 6.38 & 6.92 & \\
$\mathbf{1 0}$ & Habropoda tarsata MN919536 & 22.61 & 23.29 & 24.73 & 24.92 & 23.29 & 23.96 & 23.05 & 24.61 & 23.05 \\
$\mathbf{1 1}$ & Habropoda tarsata MN919537 & 22.61 & 23.29 & 24.06 & 24.24 & 22.76 & 23.44 & 22.36 & 24.61 & 22.51 \\
\hline
\end{tabular}

\section{Molecular evidences}

High-quality DNA sequences were obtained for the two specimens analysed, one sequence of E. gennargentui sp. nov. from Sardinia (GenBank accession number MZ437082) and one of E. alticincta bindai from Sicily (1 O; Italy, Sicily, Mount Etna, Gurrida Lake, 25.VIII.2020 RC leg., det., and coll.) (GeneBank accession number MZ437367). Both COI sequences obtained from the samples were used as queries in BOLD-IDS tools, and the system returned a match (sequence of $E$. gennargentui: $97.88 \%$; sequence of $E$. alticincta bindai: 98.77\%) with a sequence of E. alticincta present in GenBank.

Sequence divergences calculated using the $p$-distance model are reported in Table 4 , and the neighbor-joining tree showing the relationships between the new species and other related species of Eucera (Tetralonia) are reported in Fig. 7.

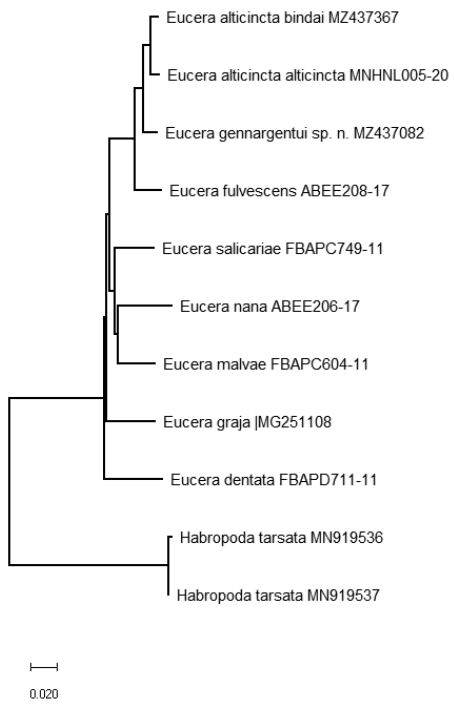

Figure 7. Neighbor-Joining tree showing relationships among Eucera gennargentui sp. nov., and Eucera (Tetralonia) species with Habropoda tarsata used as the outgroup. 


\section{Conclusion}

In the current study, Eucera fulvescens, E. julliani, and E. nana are reported for the first time for Sardinia, and E. gennargentui sp. nov. is described from Gennargentu Massif.

This new species shows a larger body size and a darker appearance than the closest related taxa E. alticincta alticincta and E. alticincta bindai, and other different characters reported in this work. Furthermore, following our field observations, we ascertained how the new species was linked to three Sardo-Corsican and Sardinian endemic botanical species of the flora of Gennargentu Massif.

The barcode sequence of the new species Eucera gennargentui diverged from that of E. alticincta alticincta from $2.08 \%$ and from that of E. alticincta bindai by $2.21 \%$.

In Europe, wild bees are threatened by habitat changes resulting from human activities, e.g., urban exspansion, agricultural practices, habitat destruction or changes, and climate changing (Matheson et al., 1996; Steffan-Dewenter et al., 2005; Nieto et al. 2014; Bella et al. 2020; Fisogni et al. 2020). There was poor information for the majority of the species (56.7\%) to determine their conservation status (Nieto et al. 2014).

In Italy, the availability of information on bees is particularly scarce, especially in southern and insular regions, so it is important to increase research to better understand the distribution and the population tendencies, especially for localised taxa.

More observations are necessary to understand the conservation status of this new species and of the other Eucera (Tetralonia) species present in Sardinia. However, the area of Gennargentu where Eucera gennargentui was found is rather restricted and subject to disturbing factors due to strong grazing regimes and reckless reforestation that inexorably damage the grasslands where the endemic host plants live. The frequency of numerous fires that devastate natural ecosystems and rural areas in Sardinia (Capra et al. 2018; Salis et al. 2021) represents a further important threat to the diversity of flora and consequently of wild bees.

The present study greatly improves the Sardinian bee fauna, showing that this Mediterranean island will surely deserves further new acquisitions, in order to increase our knowledge of its still underestimated pollinator fauna.

\section{Acknowledgements}

We thank Pietro Niolu (Alghero, Italy) for guiding us in the territory of Gennargentu Massif, and Silvia Di Silvestro (CREA, Acireale, Italy) for helping us in the genetic investigations. We also wish to thank the two reviewers, whose detailed comments and suggestions helped improve this manuscript.

\section{References}

Alfken JD (1938) Contributi alla conoscenza della fauna entomologica della Sardegna. Apidae. Memorie della Società Entomologica Italiana 16: 97-114. 
Bacchetta G, Fenu G, Guarino R, Mandis G, Mattana E, Nieddu G, Scudu C (2013) Floristic Traits and Biogeographic Characterization of the Gennargentu Massif (Sardinia). Candollea 68(2): 209-220. https://doi.org/10.15553/c2012v682a4

Banaszak J, Ortiz-Sànchez FJ (1993) Nuevas aportaciones al conocimiento de la tribu Eucerini en el sureste de España (Hymenoptera: Anthophoridae). Boletín de la Asociación española de Entomología 17(2): 263-274.

Bella S, Catania R, Nobile V, Mazzeo G (2020) New or little known bees (Hymenoptera, Apoidea) from Sicily. Fragmenta Entomologica 52(1): 113-117. https://doi.org/10.4081/ FE.2020.418

Capra GF, Tidu S, Lovreglio R, Certini G, Salis M, Bacciu V, Ganga A, Filzmoser P (2018) The impact of wildland fires on calcareous Mediterranean pedosystems (Sardinia, Italy) - An integrated multiple approach. Science of The Total Environment 624: 1152-1162. https:// doi.org/10.1016/j.scitotenv.2017.12.099

Comba M (2019) Hymenoptera: Apoidea: Anthophila of Italy. http://digilander.libero.it/ mario.comba [accessed 16 May 2021]

Dorchin A, Lopez-Uribe MM, Praz CJ, Griswold T, Danforth BN (2018) Phylogeny, new generic-level classification, and historical biogeography of the Eucera complex (Hymenoptera: Apidae). Molecular Phylogenetics and Evolution 119: 81-92. https://doi.org/10.1016/j. ympev.2017.10.007

Eardley CD (1989) The Afrotropical species of Eucara Friese, Tetralonia Spinola and Tetraloniella Ashmead (Hymenoptera: Anthophoridae). Entomology Memoir, Department of Agriculture and Water Supply, Republic of South Africa 75: 1-62.

Fisogni A, Hautekèete N, Piquot Y, Brun M, Vanappelghem C, Michez D, Massol F (2020) Urbanization drives an early spring for plants but not for pollinators. Oikos 129: 16811691. https://doi.org/10.1111/oik.07274

Folmer O, Black M, Hoeh W, Lutz R, Vrijenhoek R (1994) DNA primers for amplification of mitochondrial cytochrome c oxidase subunit I from diverse metazoan invertebrates. Molecular Marine Biology and Biotechnology 3(5): 294-299.

Grandi G (1962) Contributi alla conoscenza degli Imenotteri Aculeati. XXXI. Bollettino dell'Istituto di Entomologia dell'Università di Bologna 26: 55-101.

Kuhlmann M, Ascher JS, Dathe HH, Ebmer AW, Hartmann P, Michez D, Müller A, Patiny S, Pauly A, Praz C, Rasmont P, Risch S, Scheuchl E, Schwarz M, Terzo M, Williams PH, Amiet F, Baldock D, Berg Ø, Bogusch P, Calabuig I, Cederberg B, Gogala A, Gusenleitner F, Josan Z, Madsen HB, Nilsson A, Ødegaard F, Ortiz-Sánchez J, Paukkunen J, Pawlikowski T, Quaranta M, Roberts SPM, Sáropataki M, Schwenninger HR, Smit J, Söderman G, Tomozei B (2018) Checklist of the Western Palaearctic Bees (Hymenoptera: Apoidea: Anthophila). http://westpalbees.myspecies.info [accessed 16 May 2021]

Kumar S, Stecher G, Li M, Knyaz C, Tamura K (2018) MEGA X: Molecular Evolutionary Genetics Analysis across computing platforms. Molecular Biology and Evolution 35: 15471549. https://doi.org/10.1093/molbev/msy096

LaBerge WE (2001) Revision of the bees of the genus Tetraloniella in the New World (Hymenoptera: Apidae). Illinois Natural History Survey Bulletin 36(3): 67-162. https://doi. org/10.21900/j.inhs.v36.125 
Matheson A, Buchmann SL, O’Toole C, Westrich P, Williams IH [Eds] (1996) The conservation Biology of bees. London Academic Press, 252 pp.

Michener CD (2007) The Bees of the World [2 ${ }^{\text {nd }}$ edn.]. Johns Hopkins University Press, Baltimore, [xvi+[i]+] 953 pp. [+20 pls]

Müller A (2008) A specialized pollen-harvesting device in European bees of the genus Tetraloniella (Hymenoptera, Apidae, Eucerini). Linzer biologische Beiträge 40(1): 881-884.

Nieto A, Roberts SPM, Kemp J, Rasmont P, Kuhlmann M, García Criado M, Biesmeijer JC, Bogusch P, Dathe HH, De la Rúa P, De Meulemeester T, Dehon M, Dewulf A, Ortiz Sánchez FJ, Lhomme P, Pauly A, Potts SG, Praz C, Quaranta M, Radchenko VG, Scheuchl E, Smit J, Straka J, Terzo M, Tomozii B, Window J, Michez D (2014) European Red List of Bees. Publication Office of the European Union, Luxembourg, 84 pp.

Nobile V (1987) Contributo alla conoscenza degli Apoidei (Insecta, Hymenoptera) di Sicilia. I. I generi Habropoda Smith, Tetralonia Spinola (Gruppo “ruficornis F.”), Melecta Latreille, Eupavlovskia Popov e Thyreus Panzer. Animalia 14(1/3): 73-89.

Nobile V (1993) Endemismi di Sicilia. Tetralonia alticincta bindai, nuova sottospecie di Imenottero Apoideo. Atti e Mem., Suppl. Grifone, Ente Fauna Sicil., 1(1973-1993): 95-98.

Nobile V (1995) Api (Insecta, Hymenoptera) nuove o poco note di Sicilia e di Sardegna. Bollettino dell'Accademia Gioenia di Scienze Naturali 28(349): 147-159.

Nobile V, Catania R, Niolu P, Pusceddu M, Satta A, Floris I, Flaminio S, Bella S, Quaranta M (2021) Twenty new records of bees (Hymenoptera, Apoidea) from Sardinia (Italy). Insects 12: e627. https://doi.org/10.3390/insects 12070627

Risch S (1997) Die Arten der Gattung Eucera Scopoli 1770 (Hymenoptera, Apidae). Die Untergattung Pteneucera Tkalcu 1984. Linzer biologische Beiträge 29(1): 555-580.

Risch S (1999) Neue und wenig bekannte Arten der Gattung Eucera Scopoli 1770 (Hymenoptera, Apidae). Linzer biologische Beiträge 31(1): 115-145.

Risch S (2001) Die Arten des Genus Eucera Scopoli 1770 (Hymenoptera, Apidae) Untergattung Pareucera Tkalcu 1979. Entomofauna 22(15): 365-376.

Risch S (2003) Die Arten der Gattung Eucera Scopoli 1770 (Hymenoptera, Apidae). Die Untergattungen Stilbeucera Tkalcu 1979, Atopeucera Tkalcu 1984 und Hemieucera Sitdikov \& Pesenko 1988. Linzer biologische Beiträge 35(2): 1241-1292.

Salis M, Arca B, Del Giudice L, Palaiologou P, Alcasena-Urdiroz F, Ager A, Fiori M, Pellizzaro G, Scarpa C, Schirru M, Ventura A, Casula M, Duce P (2021) Application of simulation modeling for wildfire exposure and transmission assessment in Sardinia, Italy. International Journal of Disaster Risk Reduction 58: 1-16. https://doi.org/10.1016/j.ijdrr.2021.102189.

Saitou N, Nei M (1987) The neighbour-joining method: a new method for reconstructing phylogenetic trees. Molecular Biology and Evolution 4: 406-425.

Scheuchl E (2000) Illustrierte Bestimmungstabellen der Wildbienen Deutschlands und Österreichs. Band I: Anthophoridae. 2. erweiterte Auflage. Eigenverlag, 158 pp.

Srivathsan A, Meier R (2012) On the inappropriate use of Kimura-2-Parameter (K2P) divergences in the DNA - barcoding literature. Cladistics 28: 190-194. https://doi.org/10.111 1/j.1096-0031.2011.00370

Steffan DewenterI, Potts SG, PackerL(2005) Pollinatordiversityand crop pollination servicesareat risk. Trends in Ecology and Evolution 20(12): 651-652. https://doi.org/10.1016/j.tree.2005.09.004 
Tkalcu B (1979) Revision der europäischen Vertreter der Artengruppe von Tetralonia rufcornis (Fabricius) (Hymenoptera, Apoidea). Acta Musei Moraviae, Scientiae Naturales 64: $127-152$.

Tkalcu B (1984) Systematisches Verzeichnis der westpalaarktischen Tetralonia - und Eucera- Arten, deren Mannchen als Blutenbesucher verschiedener Ophrys-Arten festgestellt wurden. Mit Beschreibung neuer Taxa (Hymenoptera: Apoidea). Nova Acta Regiae Societatis Scientiarum Upsaliensis, Serie V, C, 3: 57-77.

Varnava AI, Roberts SPM, Michez D, Ascher JS, Petanidou T, Dimitriou S, Devalez J, Pittara M, Stavrinides MC (2020) The wild bees (Hymenoptera, Apoidea) of the island of Cyprus. ZooKeys 924(1-2): 1-114. https://doi.org/10.3897/zookeys.924.38328 